emphasize the practical steps that should be taken to implement their suggestions, including the provision of finance and the requisite personnel. Admission to the Conference will be by ticket only; applications should reach the Assistant Secretary of the Royal Society before June 1.

\section{Institution of Mechanical Engineers: Clayton Awards}

ThE Institution of Mechanical Engineers has divided the Clayton Prize for 1947 in equal moieties. One half, valued at $£ 650$, has been awarded to $\mathrm{Mr}$. J. E. Sears, formerly superintendent of the Metrology Department of the National Physical Laboratory, for his services to engineering science and manufacture by researches and development in metrology and gauging; the other half, to the value of $£ 650$, to Mr. T. E. Beacham, consulting engineer, for his contribution to the development of the variable-pitch propeller and high-speed hydraulic pumps and other hydraulic devices by way of research, invention and design.

A number of Clayton Fellowships are to be awarded during 1948 ; funds for this purpose have been derived from money bequeathed to the Institution by Mr. James Clayton, who died in 1944. Mr. Clayton was chief engineer of Messrs. Courtaulds and was closely associated with the development of equipment for the rayon industry. The Clayton Fellowships will in general be awarded for a year of postgraduate study or experience in mechanical engineering or a related science, and will be worth $£ 250-£ 500$. Candidates must be British-born subjects not less than twenty-three years old, and must possess an approved engineering degree or similar status.

\section{Marketing Agricultural Produce}

THE written evidence submitted to the Lucas Committee on the Marketing of Agricultural Produce by Mr. Thomas Shaw, on which that Committee largely based its recommendations for setting up a system of marketing for meat when the present rationing scheme and control by the Ministry of Food ends, has now been published, together with a foreword by Dr. John Hammond (from the author, Brettenham House, Lancaster Place, London, W.C.2). Insufficient attention has yet been given to the recommendation that producer marketing boards should continue to function only up to the point of procurement where the guaranteed price under the Agriculture Act applies, and that any participation in the functions of processing and marketing beyond that stage should fall within the ambit of a national slaughterhouse board or commission. Mr. Shaw's evidence details clearly the measures which the livestock industry most needs for efficiency, including complete reorganisation of the existing slaughterhouse set-up, utilization of all by-products and elimination of unnecessary profit margins, grading, division of poorer quality meats from the fresh, the manufacturing market and measures to mitigate seasonal variations in supplies. The proposed public corporation would be given powers to approve central factory abattoir schemes; to determine the terms and conditions under which such schemes should operate; to operate grading services at the abattoir and a price-governing formula; to authorize public funds required to implement the Government guarantee of prices, and linking that guarantee with qualities of the product; to make levies covering the cost of administration and the finance of industrial research in connexion with the abattoir; and to make loans to central factory abattoir schemes. The scheme, which is intended to lead to the effective closing of the wide gap between producer and consumer prices, to relieve the State in increasing measure of its financial liability under the terms of its guarantee and lay the foundations for an efficiently operating home meat industry, has thus features in common with the development councils to be established under the Industrial Organisation and Development Act, 1947, as the functions listed for the New Cotton Board, the first of such councils to be established, clearly shows.

\section{Royal Scottish Museum, Edinburgh}

A NOTABLE feature of the activities of the Royal Scottish Museum during 1946 (Ann. Rep. 1946) was the record number of temporary exhibitions that were organised. These, all of topical interest and of strong public appeal, included the "Meet Scotland" Exhibition (which ran from August 1945 until March 1946), organised by the Museum itself; "Other Peoples Jobs", organised by the Ministry of Fuel and Power, and a special health exhibition in connexion with the City of Edinburgh's Health Week. This was divided into sections dealing with maternity and child welfare, tuberculosis, school medical services, water supply, etc. A unique aspect of this particular exhibition, and one which must certainly be unique in the history of the Museum, was the presence of nursery school infants, "who," in the words of the report, "performed their exercises and ablutions, played their games and demolished their meals, completely unaffected by the mass of admiring onlookers". In reference to these and the several other special exhibitions which were provided for by various out. side organisations, Dr. D. A. Allan, director of the Museum, writes: "The scope and variety of the Museum's offerings are largely determined by the possibilities of outside assistance, and the record for 1946 provides food for thought regarding museum developments in the years ahead". The attendance figures for the various exhibitions shown on p. 3 of the report certainly justify this observation. Im. portant donations to the Museum during the year included the Fyfe collection of Japanese netsuké (presented by Mrs. E. J. Fyfe). A full list of acquisitions appears at the end of the report.

\section{British Bee Plants}

MANY people are interested in learning the sources of the pollen and nectar collected by bees; others are more concerned with the pollination of flowers; while the bee-keeper often wants to know the most suitable plants for extending pastorage for his stocks. To all of these, to botanists and to other readers we can commend the booklet "British Bee Plants" as a storehouse of useful information. All the best bee. plants are dealt with, whether they are in the flower or vegetable garden, orchard, farm or countryside. Often useful hints are given regarding cultivation of particular plants, their uses and other details. Edited by A. F. Harwood, it is issued by the Apis Club, The Ways End, Foxton, Royston, at $3 s$.

\section{British Social Hygiene Council : Summer School}

"The Schools aNd The LAND" is to be the theme of a summer school that the British Social Hygiene Council is organising at the Seale-Hayne Agricultural College, Newton Abbot, Devon, during July 30 August 13. The school will be concerned with the 
place of agriculture in the life of the nation, with special reference to the soil, its cultivation and improvement, grassland and arable crops, livestock husbandry, the processing and distribution of farm products, and the social and economic conditions of rural life. The school should appeal particularly to all teachers of biology, and social workers and others will be able to extend their knowledge of and sympathy with the work, outlook and social conditions of the rural community.

At the evening sessions, lectures will be given by visiting speakers, each expert in his special field. Among those who have already accepted invitations to speak are the Rt. Hon. R. K. Law, Prof. A. W. Ling, Prof. 'T. Wallace, Prof. D. B. Johnstone-Wallace, Mr. L. J. F. Brimble, Mr. J. H. Anderson, Mr. E. Ford, Mr. G. F. Kingston, Mr. K. C. Vear and Dr. D. A. MacPherson. The resident staff will consist of Mr. A. Roebuck, Miss H. R. Chapman, Mr. W. L. Sumner, Mr. E. Lucas, Mr. L. E. Morris, Mr. R. Weatherall and Dr. M. B. Gibbons. The fee for the School is $£ 14$ 14s. (including £l 1s. enrolment fee-not returnable). This covers board and tuition. Further information can be obtained from the Secretary, British Social Hygiene Council, Dept. S.J.1, Tavistock House North, Tavistock Square, London, W.C.1.

\section{University of Leeds: Appointments}

THE following appointments in the University of Leeds have been announced: Dr. J. W. Baker, formerly senior lecturer and honorary reader in organic chemistry, to the newly established readership in the mechanism of organic reactions; Dr. C. S. Whewell, lecturer in textile chemistry, to be honorary reader in textile finishing and lecturer in textile chemistry.

\section{University of Sheffield}

THE following appointments in the University of Sheffield have been announced : O. I. Butler, senior lecturer in charge of the Department of Electrical Engineering; H. J. Cowan, lecturer in civil engineering ; G. Wiseman, assistant lecturer in physiology ; A. G. Macgregor, research assistant in the Department of Pharmacology and Therapeutics.

Prof. Douglas Knoop, who is retiring from the chair of economics at the end of the present session, has made a gift of money to the University to endow an economics prize, to be associated with his name, to be awarded to the student whose work in economics in the final examination for the Special Degree of B.A. has shown most distinction and promise.

\section{Colonial Service : Appointments}

THE following appointments in the Colonial Service have been announced: D. D. Campbell, agricultural officer, Uganda; H. Irving, agricultural chemist, Nigeria ; D. C. Todd, agricultural officer, Uganda; G. H. Pinfield, inspector of mines, Tanganyika; L. F. Edgerley, assistant conservator of forests, Mauritius; B. R. Fuller, assistant conservator of forests, Nyasaland; S. T. Hoyle, senior agricultural officer, Lilongwe Experimental Station, Nyasaland; J. Sinclair, curator of the Herbarium, Singapore; S. Gillet (senior coffee officer, Kenya), director of agriculture, Kenya ; J. T. Moon (agricultural officer, Kenya), senior agricultural officer, Kenya; C. C. Parisionos (agricultural officer, Northern Rhodesia), agricultural officer, Cyprus ; A. Pickles (entomologist, Trinidad), entomologist, Nigeria; F. W. Thomas (agricultural officer, Tanganyika), senior agricultural officer, Tanganyika; J. P. Edwards (conservator of forests, Malaya), deputy director of forestry, Malaya; R. O. Roberts (chemist and petrologist, Uganda), mineralogist, Nigeria ; D. F. Macpherson (senior veterinary officer, Kenya), chief veterinary officer, Nyasaland; F. L. Vanderplank (research officer, Tanganyika), entomologist, West African Institute for Trypanosomiasis.

\section{The Night Sky in April}

New moon occurs on April 9d. 13h. 16m., U.T., and full moon on April 23d. 13h. 28m. The following conjunctions with the moon take place: April 7d. 18h., Mercury $2^{\circ}$ N.; April 13d. 08h., Venus $1^{\circ}$ N.; April 18d. 02h., Saturn $4^{\circ}$ S. ; April 18d. 10h., Mars $3^{\circ}$ S. ; April 27d. 18h., Jupiter $4^{\circ}$ N. ; Mercury, in superior conjunction with the sun on April 29, is too close to the sun during the month for favourable observation. Venus is an evening star, setting at $22 \mathrm{~h} .56 \mathrm{~m}$. and $23 \mathrm{~h} .45 \mathrm{~m}$. on April 1 and 30 respectively, and shines with stellar magnitude -4 approximately during the month, about one half of the illuminated portion of the disk being visible. The planet attains its greatest easterly elongation on April 15. Mars, in the constellation of Leo, can be seen throughout the greater portion of the night, setting at $4 \mathrm{~h}$. $25 \mathrm{~m} ., 3 \mathrm{~h} .23 \mathrm{~m}$., and $2 \mathrm{~h} .4 \mathrm{~lm}$., at the beginning, middle and end of the month, respectively. Jupiter, in the constellation of Sagittarius, is not visible until the early morning hours, the times of rising being $1 \mathrm{~h} .25 \mathrm{~m}$. on April 1 and $23 \mathrm{~h}$. $30 \mathrm{~m}$. on April 30. The planet is stationary on April 15. Saturn, in the constellation of Cancer, is visible during most of the night, setting a little before Mars, and is stationary on April 17. Occultations of stars brighter than magnitude 6 are as follows: April 13d. 20h. 3lm., $k$ Taur. $(D)$; April 26d. 00h. I6m. 19 Scor. $(R) ; D$ and $R$ refer to disappearance and reappearance, respectively, and the latitude of Greenwich is assumed. There will be a partial eclipse of the moon on April 23, invisible at Greenwich, but visible over a large portion of the southern hemisphere and also over the extreme western and north. western portion of North America. The Lyrid meteors can be seen during April 18-24, but moonlight will partly interfere with the observations of this shower.

\section{Announcements}

THE governing body of the Imperial College of Science and Technology has appointed Air Chief Marshal Sir Roderic Hill to be rector of the College as from October 1, in succession to Sir Richard Southwell, who has held that office since 1942.

Dr. J. Cymerman, lecturer in organic chemistry in Charing Cross Hospital Medical School (University of London), has been appointed lecturer in organic chemistry in the University of Sydney.

Tre following have been elected officers of the Royal Photographic Society: President, Percy W. Harris; Vice-Presidents, L. V. Chilton, I. D. Wratten ; Treasurer, H. Abbott; Ordinary Members of Council, Gilbert Adams, J. Allan Cash, K. H. Gaseltine, R. N. Haile, Dr. P. Hansell, T. Midgley Illingworth, Dr. S. D. Jouhar, Mrs. Rosalind Main. got, R. H. Mason, H. S. Newcombe, Alec Pearlman, Anthony Peacock, Oliver G. Pike, B. Sinkinson, A. L. M. Sowerby. 